\title{
Twenty-one Year Trends for Shorebirds, Waterfowl, and Other Waterbirds at Great Salt Lake, Utah
}

\section{Brian G. Tavernia, Tim Meehan, John Neill, John Luft}

\begin{abstract}
Millions of wetland-dependent birds annually depend on saline lakes and associated wetlands in the western United States. Understanding the population status and trends of birds with different life histories and habitats can guide efforts to secure water resources needed to sustain bird habitats. We used a 21-year dataset to examine population trends for 24 survey units presumed to be high-quality habitat for migratory shorebirds, waterfowl, and other waterbirds at Great Salt Lake and associated wetlands. As expected for high-quality habitats, we found stable or positive trends for 36 of 37 species or groups in fall, spring, or both seasons when considering survey units in aggregate. Despite stable or positive aggregate trends, negative trends did occur in some individual survey units. Foraging, migration distance, and taxonomic groupings were unrelated to trend direction. Research is needed to test whether survey units represent high-quality habitat. With declining regional water resources, stable and positive aggregate trends reinforce the importance of surveyed units at Great Salt Lake and associated wetlands to wetland-dependent birds. Ensuring continuation of stable and positive trends will require identifying environmental factors - including water quantity and quality - driving trends, and require coordinated regional management and monitoring of wetland-dependent birds.
\end{abstract}

Brian Tavernia National Audubon Society, Salt Lake City, UT 84101, USA

Tim Meehan National Audubon Society, Boulder, CO 80305, USA

John Neill, John Luft Utah Division of Wildlife Resources, Hooper, UT 84315, USA

Keywords : Bayesian; Great Salt Lake; guilds; hydrology; saline lake; shorebird; trends analysis; waterbird; waterfowl; wetlands

Introduction The saline lakes of the western United States and their associated wetlands support millions of shorebirds, waterfowl, and other waterbirds on an annual basis (Aldrich and Paul 2002; Petrie et al. 2013; Wilsey et al. 2017). Bird use of these systems is driven by multiple factors including the predominantly xeric conditions of the western United States, spatially and temporally dynamic water depths, diverse salinities and dynamic wetland habitats, the presence of islands for nesting within lakes, and abundant food resources (Aldrich and Paul 2002; Wilsey et al. 2017; Sorensen et al. 2020). The factors that determine habitat value are affected indirectly or directly by saline lakes' water levels, which depend on the balance among water inflows, precipitation, and evaporative water loss. For example, brine shrimp (Artemia spp.), an important invertebrate food re- source at some lakes, are sensitive to salinity changes caused by receding or rising lake levels (Dana and Lenz 1986; Senner et al. 2018). Water diversions and extractions for anthropogenic uses, such as irrigated agriculture, have historically reduced water inflows to saline lakes and associated wetlands (Wurtsbaugh et al. 2017; Donnelly et al. 2020) and, in combination with climate change (e.g., potential for reduced streamflow), will continue to affect water levels, timing, and salinity in the future (Ficklin et al. 2013; Jeppesen et al. 2015; Meixner et al. 2016). Efforts to protect and restore water flows for saline lakes and associated wetland habitat can benefit from understanding the population status and trends of bird species with different life histories and habitat requirements.

Population trend assessments depend on 
monitoring, or the process of making and analyzing repeated observations of species' attributes to track changes in their status across time (Thompson et al. 1998). By supplying estimates of species distributions, population sizes, or trends, monitoring data inform species prioritization for conservation actions given available resources. Multiple prioritization systems assign greater priority to species with smaller distributions and population sizes and declining trends, and conservation plans have used these factors to prioritize shorebird and waterbird species (Brown et al. 2001; Kushlan et al. 2002). Beyond species prioritization, trend assessments can be used to suggest conservation strategies and tactics to benefit species and the habitats on which they rely. The potential for these suggestions is realized if researchers identify life history (e.g., migration strategy) or ecological (e.g., habitat use) traits shared in common by species with decreasing, stable, or increasing trends. For example, wetland birds capable of using artificial waterbodies, such as impoundments, may increase with agricultural and urban development in arid regions whereas those dependent on natural wetlands may decrease (Okes et al. 2008). In such regions, conservationists may focus on protecting remaining natural wetlands and restoring degraded areas by, for example, managing water inflows.

Trends for specific sites may not reflect the overall trajectory of a species' regional population if surveyed sites are not representative of available habitat, and this must be weighed when interpreting trends to inform conservation and management actions. As one example, populations have been shown to be relatively invariable in perceived high-quality habitat when compared to population fluctuations in lower quality sites (Kluyver and Tinbergen 1953; Gill et al. 2001). Lower quality sites are said to 'buffer' fluctuations in higher quality sites, and this buffering could result from differences in survival, reproduction, or active habitat selection of high-quality sites (Kluyver and Tinbergen 1953). Thus, lower quality sites potentially reflect changes in overall population size to a greater degree than higher quality areas (Gill et al. 2001). Accordingly, trends based on surveys of highquality habitat sites may not detect overall population declines until such declines have progressed enough

Submitted to Waterbirds and In Review to become apparent in high-quality habitat. Similarly, omission of some high-quality habitat types (e.g., shorebird playa habitat), such that sampled habitat types are incomplete, may result in survey trends that do not reflect trends in the regional population.

Great Salt Lake, the largest saline lake in the Great Basin, and its associated wetlands are recognized regionally, nationally, and hemispherically as important sites for shorebirds, waterfowl, and other waterbirds (Aldrich and Paul 2002; Chipley et al. 2003). As with other saline lakes, anthropogenic water diversions have reduced water inflows to Great Salt Lake and associated wetlands (Wurtsbaugh et al. 2017), and climate change may cause regional shifts from snow to rainfall, changes in snowmelt timing, and increased evapotranspiration that contribute to water inflow reductions in the future (Baxter and Butler 2020). Local and regional plans and other documents have identified priority migratory shorebird, waterfowl, and other waterbird species that depend on Great Salt Lake and have called for quantifying flows necessary to provide habitat for these species (Ivey and Herziger 2006; Petrie et al. 2013; Sorensen et al. 2018).

In this study, we used a 21-year monitoring dataset to analyze trends of migratory shorebird, waterfowl, and other waterbirds in high bird-use areas of Great Salt Lake and its associated wetlands. In conducting analyses, our objectives were to (1) estimate population trends during fall and spring migration for individual species and species groups; (2) determine whether trends differed for different areas of the lake and associated wetlands; and (3) evaluate whether trends were associated with particular taxonomic groups, migratory strategies, or foraging techniques. With a focus on high-use areas of presumably high habitat quality, we predicted most species and species groups would show stable trends. Ultimately, we aimed to provide trend estimates that can inform future discussions about species prioritization and to identify traits shared by species showing increasing, decreasing, or stable trends to inform the formulation of conservation strategies.

Methods Study Area Unless another citation is provided, the description of Great Salt Lake (Fig. 1) is based on information in Aldrich and Paul (2002) who 


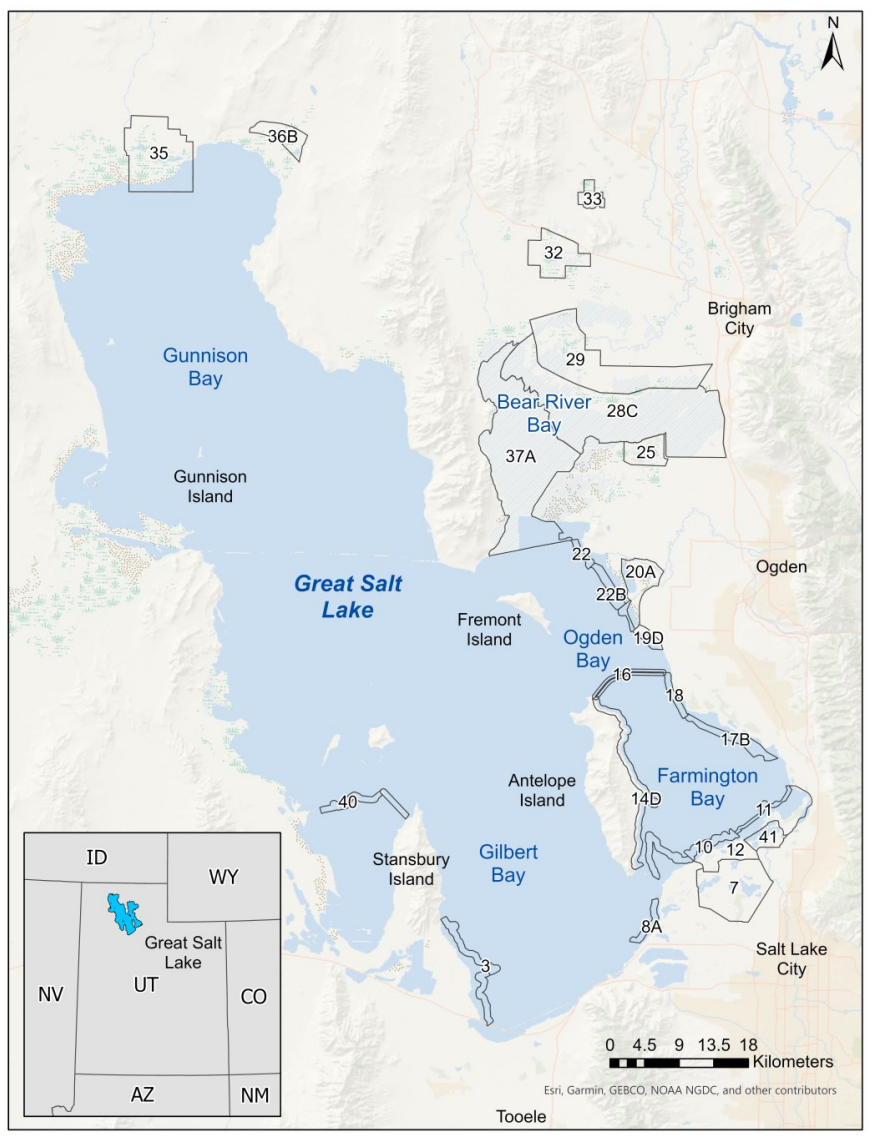

Fig. 1 Locations of 24 survey units where the Great Salt Lake Ecosystem Program conducts long-term surveys for migratory shorebirds, waterfowl, and other waterbirds at Great Salt Lake, Utah

described the lake's ecological setting from an avian perspective. The lake is located in a cold desert environment with local annual precipitation ranging from $25 \mathrm{~cm}$ to $38 \mathrm{~cm}$ on its west and east sides, respectively. Temperatures frequently reach $-18^{\circ} \mathrm{C}$ during winter and $38^{\circ} \mathrm{C}$ during summer. The lake is one of a relatively few locations where migratory wetland birds may find habitat for staging and molting in an otherwise arid region. As with other saline lakes, water enters through surface water, groundwater flows, and precipitation and naturally exits via evaporation (Null and Wurtsbaugh 2020). These hydrological processes have led and continue to lead to the accumulation of salts in the lake. Freshwater inflows predominantly from the Bear, Weber, and Jordan rivers into this terminal lake create a continuum of freshwater, brackish, and saline wetland habitats for bird use. Other inflows are from smaller tributaries, groundwater, sewage plants, and precipitation. Based on National Wetlands Inventory data (U.S. Fish and Wildlife Service 2019), the 5 counties (Box Elder, Davis, Salt Lake, Tooele, and Weber) spatially adjacent to and including Great Salt Lake contain 1.4 million ha of lake; 70,583 ha of freshwater emergent wetland; 22,335 ha of riverine wetlands; 8,357 ha of freshwater pond; and 1,056 ha of freshwater forest/shrub wetland.

The plant composition of Great Salt Lake wetlands responds to salinity, hydroperiod, and water depth. Freshwater wetlands tend to host plant species such as cattail (Typha spp.), sago pondweed (Stuckenia pectinata), and hardstem bulrush (Schoenoplectus acutus) whereas examples from more saline wetlands include muskgrass (Chara spp.) and alkali bulrush (Bolboschoenus maritimus). Shorebirds will use mudflats vegetated by pickleweed (Salicornia spp.) and wet meadows with saltgrass (Distichlis spicata) (Sorensen et al. 2020). Invasion by common reed (Phragmites australis) can reduce or eliminate wetland habitat suitability for birds (Benoit and Askins 1999), and managers expend considerable effort and great expense to control such invasions at Great Salt Lake (Rohal et al. 2018). Shorebird, waterfowl, and other waterbird use of wetland plants and habitats more generally at Great Salt Lake is reviewed by Sorensen et al. (2020) and Downard et al. (2017). Bird diets at Great Salt Lake may be primarily herbivorous, insectivorous, piscivorous, or omnivorous with dietary status varying from species-to-species and season-toseason (Barber and Cavitt 2012). Some birds, such as the Eared Grebe (Podiceps nigricollis) and Wilson's Phalarope (Phalaropus tricolor), are particularly dependent on halophilic brine shrimp (A.franciscana) and brine flies (Ephydra spp.) as food resources (Conover and Caudell 2009; Roberts 2013).

Variable inflows, evaporative water loss, lake surface elevation, and a low gradient bottom interact and result in changes in the types and extents of wetland habitats present over seasonal, annual, and decadal periods. As an example, an increase in lake elevation from 1,277.5 m (observed in 1963) to $1,283.8 \mathrm{~m}$ (1986) more than doubles the surface area of the lake (Cruff 1986). These water dynamics generally create productive ecological conditions for migratory birds, but extreme fluctuations can negatively affect birds for a short time by, for example, flooding nesting areas. These fluctuations are overlaid on a downward trend in lake level. Since the arrival of European set- 
tlers in 1847, water development and river diversions for agricultural, industrial, and urban purposes have reduced water flow into the lake, resulting in the lake being approximately $3.4 \mathrm{~m}$ lower in elevation than it otherwise would have been (Wurtsbaugh et al. 2017). Continued anthropogenic water use and climate change have the potential to drive additional declines in lake elevation in the future. Recent projections suggest that precipitation and temperature changes are capable of relatively large impacts on lake elevation whereas water conservation efforts (e.g., increased municipal water and industrial use efficiency) can have a positive, although relatively small, effect on lake elevation (Jacobs Engineering Group Inc. 2019).

Bird Survey Data Observers counted birds at 24 survey units within Great Salt Lake or wetlands associated with the lake (Fig. 1, Table 1). We limited surveys to bird species in the following families: Gaviidae, Podicipedidae, Pelecanidae, Phalacrocoracidae, Ardeidae, Threskiornithidae, Anatidae, Rallidae, Gruidae, Charadriidae, Recurvirostridae, Scolopacidae, and Laridae. We selected survey unit locations representing dike edge, open water, shoreline, and wetland habitats in areas heavily used by species in these families (Paul and Manning 2002). We established survey unit boundaries (median size: 1,495.8 ha; Table 1) based on the edges of habitat patches and the ability to complete surveys within 4 hours.

Depending on habitat and means of access, observers used either area counts or aerial surveys to count birds within survey units (Table 1). For some units, area or aerial counts were conducted for separate subunits and these counts later aggregated into a total count for the unit (see below). Area counts involved recording all birds seen or heard within a unit while traveling standardized routes (e.g., dike roadways) or transects. Area counts might not cover the entire survey unit due to inaccessibility or visual obstruction by emergent vegetation. The number of observers for an area count depended on challenges associated with the unit, such as unit size and the number of birds typically present. For area counts of shoreline habitats, observers traveled transects. Transects began at a designated starting point and paralleled the shoreline at a perpendicular distance of approximately $91 \mathrm{~m}$. Observers recorded all birds within a 402-m buffer while traveling transects. Across surveys within and between years, observers shifted transects perpendicularly to maintain a distance of $91 \mathrm{~m}$ from the shoreline as Great Salt Lake's water level waxed and waned. From 1997 - 2001, observers stopped at randomly selected points along shoreline transects to conduct 10-minute point counts. This practice was discontinued in following years.

Observers aerially surveyed two large units within Bear River Bay. For aerial surveys, we established 463-m wide transects spaced approximately 1,852-m apart within survey units. During flights, observers used a GPS unit to locate transect start and ending points. Flight speeds and altitudes ranged from 129 to $161 \mathrm{~km} / \mathrm{h}$ and 24 to $61 \mathrm{~m}$, respectively. Counts were conducted by two observers with each observer counting species observed out to $231.5 \mathrm{~m}$ from the plane. Since transects in aggregate covered only a quarter of the survey unit, we extrapolated transect counts to the entire survey unit by multiplying total counts across transects by a factor of four.

Observers included professional wildlife biologists, field technicians, and volunteers. Across years, 17 of 24 survey units were consistently counted by either wildlife biologists and their field technicians or volunteers whereas professional status was inconsistent for the other survey units. While individual observers changed with time, sometimes annually, wildlife biologists or volunteers with long-standing experience generally supervised counts for their respective units each year. We assumed that changes in professional status and observer identity would add noise to data but not result in biased trends.

Surveys varied in frequency and duration across three phases. From 1997 through 2001, observers annually surveyed units every 10 days. In 1997, surveys began in late June and lasted through midSeptember whereas, for the remaining years, surveys began in April and lasted through September (for 17 total surveys). Between 2004 and 2006, annual surveys occurred three and nine times during spring (15 April - 14 May) and fall (8 July - 5 September) migration seasons, respectively. Since 2007, surveys have been conducted twice during spring (10 April - 9 May) migration and three times during fall migration 
bioRxiv preprint doi: https://doi.org/10.1101/2021.05.17.444474; this version posted May 17, 2021. The copyright holder for this preprint (which Submitted to Waterbirds and In Review available under aCC-BY-NC-ND 4.0 International license.

Table 1. Characteristics of 24 survey units where the Great Salt Lake Ecosystem Program conducts long-term surveys for migratory shorebirds, waterfowl, and other waterbirds at Great Salt Lake, Utah. Habitat indicates whether a unit is predominantly dike edge (D), open water $(\mathrm{O})$, shoreline $(\mathrm{S})$, or wetland (W). The area of each unit is reported with the percentage of the unit surveyed reported parenthetically. The years in which the unit was surveyed and included in trends analyses are reported.

\begin{tabular}{|c|c|c|c|}
\hline Unit & Habitat & Area (ha) & Survey Years Analyzed \\
\hline 3 & $\mathrm{~S}$ & $\begin{array}{c}1,725.8 \\
(100)\end{array}$ & $1997-2001 ; 2004-2017$ \\
\hline 7 & $\mathrm{~W}$ & $\begin{array}{c}5,910.5 \\
(15)\end{array}$ & $1997-2001 ; 2004-2017$ \\
\hline $8 \mathrm{~A}$ & $\mathrm{~S}$ & $\begin{array}{l}580.3 \\
(100)\end{array}$ & $1997-2001 ; 2004-2006 ; 2009 ; 2012 ; 2015$ \\
\hline 10 & W & $\begin{array}{l}768.1 \\
(100)\end{array}$ & $1997-2001 ; 2004-2017$ \\
\hline 11 & $\mathrm{~W} / \mathrm{D}$ & $\begin{array}{l}522.2 \\
(100)\end{array}$ & $1997-2001 ; 2004-2007 ; 2010 ; 2013 ; 2014 ; 2016$ \\
\hline 12 & $\mathrm{~W}$ & $\begin{array}{c}4,544.5 \\
(65)\end{array}$ & $1997-2001 ; 2004-2006 ; 2008-2017$ \\
\hline $14 \mathrm{D}$ & $\mathrm{S}$ & $\begin{array}{c}3,509.5 \\
(100)\end{array}$ & $1997-2001 ; 2006-2017$ \\
\hline 16 & $\mathrm{D} / \mathrm{S}$ & $\begin{array}{l}849.8 \\
(100)\end{array}$ & $2004-2017$ \\
\hline 17B & $\mathrm{S}$ & $\begin{array}{c}1,331.8 \\
(100)\end{array}$ & $1997-2001 ; 2004-2006 ; 2009 ; 2012 ; 2015$ \\
\hline 18 & $\mathrm{~S}$ & $\begin{array}{l}525.9 \\
(100)\end{array}$ & $1997-2001 ; 2004-2006$ \\
\hline 19D & $\mathrm{W}$ & $\begin{array}{c}569.3 \\
(85)\end{array}$ & $2004-2017$ \\
\hline $20 \mathrm{~A}$ & W & $\begin{array}{l}2,495.6 \\
(60)\end{array}$ & $2004-2017$ \\
\hline 22 & $\mathrm{~S}$ & $\begin{array}{l}389.4 \\
(100)\end{array}$ & $1998-2001 ; 2007 ; 2010 ; 2013 ; 2016$ \\
\hline $22 \mathrm{~B}$ & $\mathrm{~W} / \mathrm{S}$ & $\begin{array}{l}850.5 \\
(100)\end{array}$ & $2007 ; 2010 ; 2013 ; 2016$ \\
\hline 25 & $\mathrm{~W}$ & $\begin{array}{l}1,773.4 \\
(33)\end{array}$ & $1997-2001 ; 2004-2012 ; 2014-2017$ \\
\hline $28 \mathrm{C}$ & $\mathrm{W}$ & $\begin{array}{l}19,870.9 \\
(100)\end{array}$ & $2004-2017$ \\
\hline 29 & $\mathrm{~W}$ & $\begin{array}{l}10,449.4 \\
(30)\end{array}$ & $1997-1999 ; 2004-2007 ; 2009-2017$ \\
\hline 32 & $\mathrm{~W}$ & $\begin{array}{l}3,248.7 \\
(20)\end{array}$ & 1997 -2001; 2004 - 2006; 2008; 2011; 2014; 2017 \\
\hline 33 & $\mathrm{~W}$ & $\begin{array}{c}863.4 \\
(35)\end{array}$ & $1997-2001 ; 2008 ; 2011 ; 2014 ; 2016-2017$ \\
\hline 35 & W & $\begin{array}{c}7,607.9 \\
(4)\end{array}$ & 1997; 2001; $2004-2007 ; 2010 ; 2013-2014 ; 2016$ \\
\hline $36 \mathrm{~B}$ & $\mathrm{~W}$ & $\begin{array}{l}1,659.8 \\
(40)\end{array}$ & $1998-2001 ; 2004-2006 ; 2009 ; 2012 ; 2015$ \\
\hline $37 \mathrm{~A}$ & $\mathrm{O}$ & $\begin{array}{l}17,955.2 \\
(100)\end{array}$ & $2004-2017$ \\
\hline 40 & $\mathrm{D}$ & $\begin{array}{c}752 \\
(100)\end{array}$ & $1998-2001 ; 2004-2006$ \\
\hline 41 & $\mathrm{~W}$ & $\begin{array}{c}1,200.2 \\
(50)\end{array}$ & 1999; 2001; 2004 - 2006; 2009; 2012; 2015 \\
\hline
\end{tabular}

(18 July - 31 Aug) with some units surveyed on an annual basis and others triennially. Not all survey units were surveyed during each of the three phases or with the same frequency (Table 1), so the number of years with survey data ranged from 4 to 19 (median:
13.5 years) across survey units.

To enable trends analyses, we identified and retained surveys conducted only during periods common to all three phases. There were five such periods, 
including Period 1, from 10 April through 24 April; Period 2, from 25 April through 9 May; Period 3, from 18 July through 1 August; Period 4, from $2 \mathrm{Au}-$ gust through 16 August; and Period 5, from 17 August through 31 August. Periods 1 and 2 were classified as spring migration counts, and Periods 3,4 , and 5 were classified as fall migration counts. When multiple counts occurred for a survey unit during a survey period, we averaged counts and rounded to the nearest integer value. For those units with surveys conducted in subunits, we averaged subunit counts per period and then summed the averaged subunit counts. After binning counts into the five common survey periods, we aggregated counts a final time into the two migration seasons by taking the maximum count from periods 1 and 2 for spring migration and the maximum count from periods 3,4 , and 5 for fall migration.

We eliminated 77 species or groups that were rare (i.e., observed on $<20$ percent of counts) because modeling of sparse data was not expected to yield robust trend estimates. The list of eliminated species and groups is available upon request. We aggregated counts for 20 species we considered difficult for observers to distinguish in the field, producing counts for seven species groups (Table 2). For example, Clark's Grebe (Aechmophorus clarkii), Western Grebes (A. occidentalis), and Clark's/Western Grebe were grouped together and labeled Aechmophorus. Counts for 30 other species remained disaggregated during trends analyses (Table 3). Thus, we retained 37 species or groups, and, for each species or group, the maximum count per survey unit, migration season, and year was used for trend analysis.

Species Traits Previous researchers have used nesting, foraging, and migration behaviors to evaluate the response of wetland bird species and communities to natural or anthropogenic disturbances (DeLuca et al. 2004; Crewe and Timmermans 2005). With a focus on migration seasons, we categorized species based on their foraging techniques, migration strategy, and taxonomic group (Table 3). We did not categorize species groups because foraging technique and migration strategy varied across a group's constituents in some cases. We assigned a primary foraging technique to each species after Ehrlich et al. (1988) who made assignments based on the breeding season. As our focus
Table 2. Groups used to aggregate counts for species difficult to identify in the field during surveys conducted by the Great Salt Lake Ecosystem Program at Great Salt Lake, Utah.

\begin{tabular}{|c|c|}
\hline Group & Species \\
\hline \multirow[t]{3}{*}{ Aechmophorus } & Clark's Grebe \\
\hline & Western Grebe \\
\hline & Clark's/Western Grebe \\
\hline \multirow[t]{4}{*}{ Aythya } & Greater Scaup \\
\hline & Lesser Scaup \\
\hline & Ring-necked Duck \\
\hline & Unidentified Scaup \\
\hline \multirow[t]{4}{*}{ Egrets } & Cattle Egret \\
\hline & Great Egret \\
\hline & Snowy Egret \\
\hline & Unidentified Egret \\
\hline \multirow[t]{3}{*}{ Gulls } & California Gull \\
\hline & Ring-billed Gull \\
\hline & Unidentified Gull \\
\hline \multirow[t]{3}{*}{ Phalaropus } & Red-necked Phalarope \\
\hline & Wilson's Phalarope \\
\hline & Unidentified Phalarope \\
\hline \multirow[t]{7}{*}{ Sandpipers } & Baird's Sandpiper \\
\hline & Least Sandpiper \\
\hline & Sanderling \\
\hline & Semipalmated Sandpiper \\
\hline & Spotted Sandpiper \\
\hline & Western Sandpiper \\
\hline & Unidentified Sandpiper \\
\hline \multirow[t]{3}{*}{ Yellowlegs } & Greater Yellowlegs \\
\hline & Lesser Yellowlegs \\
\hline & Unidentified Yellowlegs \\
\hline
\end{tabular}

was on birds during migration, we revised assigned techniques as needed based on nonbreeding foraging behaviors and food items reported in species accounts of Rodewald (2015) and by the studies of Cavitt (2006), Barber and Cavitt (2012), and Roberts (2013).

We identified species as being either short$(\leq 2000 \mathrm{~km})$ or long-distance $(>2000 \mathrm{~km})$ migrants (Zaifman et al. 2017). We followed a procedure for 

Submitted to Waterbirds and In Review available under aCC-BY-NC-ND 4.0 International license.

Table 3. Species-specific foraging techniques, migration distances, and taxonomic groups. Foraging techniques after Ehrlich et al. (1988) and modified based on Cavitt (2006), Barber and Cavitt (2012), Roberts (2013), and Rodewald (2015). Migration distance represents the distance between centroids of nonbreeding and breeding ranges within North and South America as represented by Birdlife International and Handbook of the Birds of the World (2018). For Black-necked Stilt, nonbreeding and breeding ranges were digitized from Cornell Lab of Ornithology (2020). Species migrating $\leq 2000 \mathrm{~km}$ were considered short-distance migrants whereas those migrating $>2000 \mathrm{~km}$ were labeled long-distance migrants. Taxonomic group assigned based on Clements et al. (2019). Shorebird included species from the order Charadriiformes with the exception of family Laridae whereas waterfowl encompassed species within the order Anseriformes. All other species were considered other waterbirds.

\begin{tabular}{lccc}
\hline Species & Foraging Technique & Migration Distance $(\mathrm{km})$ & Taxonomic Group \\
\hline American Avocet & Sweeps & 1,821 & Shorebird \\
\hline American Coot & Surface Dips & 994 & Waterbird \\
\hline American Wigeon & Dabbles & 2,796 & Waterfowl \\
\hline American White Pelican & Surface Dips & 2,468 & Waterbird \\
Black-crowned Night-Heron & Stalk and Strike & 1,605 & Waterbird \\
Black-necked Stilt & Ground Glean & 1,319 & Shorebird \\
Canada Goose & Surface Dips & 1,544 & Waterfowl \\
Caspian Tern & High Dives & 3,001 & Waterbird \\
\hline Cinnamon Teal & Surface Dips & 2,178 & Waterfowl \\
\hline Double-crested Cormorant & Surface Dives & 1,228 & Waterbird \\
\hline Eared Grebe & Surface Dives & 1,500 & Waterbird \\
Forster's Tern & High Dives & 2,327 & Waterbird \\
\hline Franklin's Gull & Ground Glean & 9,028 & Waterbird \\
Gadwall & Dabbles & 1,246 & Waterfowl \\
Great Blue Heron & Stalk and Strike & 1,218 & Waterbird \\
Green-winged Teal & Dabbles & 2,442 & Waterfowl \\
\hline Killdeer & Ground Glean & 1,437 & Shorebird \\
\hline Long-billed Curlew & Ground Glean & 1,937 & Shorebird \\
\hline Long-billed Dowitcher & Probes & 5,640 & Shorebird \\
Marbled Godwit & Probes & 2,290 & Shorebird \\
\hline Mallard & Dabbles & 1,521 & Waterfowl \\
Northern Pintail & Dabbles & 3,392 & Waterfowl \\
\hline Northern Shoveler & Surface Dips & 2,949 & Waterfowl \\
\hline Pied-billed Grebe & Surface Dives & 1,256 & Waterbird \\
\hline Redhead & Surface Dives & 1,958 & Waterfowl \\
\hline Ruddy Duck & Surface Dives & 1,169 & Waterfowl \\
\hline Sandhill Crane & Ground Glean & 3,299 & Waterbird \\
\hline Snowy Plover & Ground Glean & 1,468 & Shorebird \\
\hline White-faced Ibis & Ground Glean & 797 & Waterbird \\
\hline Willet & Ground Glean & 3,684 & Shorebird \\
\hline & & & \\
\hline
\end{tabular}


determining migration distance similar to Galbraith et al. (2014). Specifically, we quantified the distance between centroids of nonbreeding and breeding ranges as represented by geospatial data of Birdlife International and Handbook of the Birds of the World (2018). Nonbreeding ranges included areas where species were known or thought to be extant, native, and present throughout the year or during the nonbreeding season. Breeding ranges included areas where species were known or thought to be extant, native, and present throughout the year or during the breeding season. We clipped ranges to the boundaries of the North and South American continents (ESRI 2019). The Black-necked Stilt (Himantopus mexicanus) was not included in Birdlife International and Handbook of the Birds of the World (2018). We manually digitized this species' geographic range from North and South America using maps made available by Cornell Lab of Ornithology (2020). All geospatial processing and analyses were carried out in ArcGIS Pro 2.4.1 (ESRI, Redlands, CA).

We assigned species to broad taxonomic categories of shorebird, waterfowl, and other waterbirds based on Clements et al. (2019). The shorebird category included species from the order Charadriiformes with the exception of family Laridae whereas waterfowl encompassed all species within the order Anseriformes. All other species were considered waterbirds (Table 3).

Statistical Analysis For each species and group, we conducted two independent trend analyses, one using maximum counts from the spring migration season, and one using maximum counts from the fall migration season. We modeled each maximum count, $y_{i, t}$, per survey unit $i$ during year $t$, as a random variable from a negative binomial distribution. Expected values for maximum counts per study area and year, $\mu_{i, t}$, were modeled with the linear predictor, $\log \left(\mu_{i, t}\right)=\beta_{0}+$ $\beta_{1} Y+v_{t}+\kappa_{i}+\tau_{i}$, where $\beta_{0}$ was a global intercept, $\beta_{1}$ was a global log-linear effect of year $Y, v_{t}$ was a random intercept deviation per year $t, \kappa_{i}$ was a random intercept deviation per study area $i$, and $\tau_{i}$ was a random slope deviation per study area $i$.

The model was analyzed in a Bayesian context using the INLA v20.03.17 package (Rue et al. 2017) for R statistical computing software ( $\mathrm{R}$ Core Team 2020). The two global effects were assigned normal prior distributions with a mean $=0$ and $\mathrm{SD}=100$. The three random terms were unstructured, zero-centered, normally distributed, exchangeable effects with penalized complexity priors for the spreads of distributions (Simpson et al. 2017). The penalized complexity priors for random intercept deviations were specified such that probability of an $\mathrm{SD} \geq 2.00$ was 0.01 . The penalized complexity prior for random slope deviations was specified such that probability of an SD $\geq$ 0.50 was 0.01 . A negative binomial distribution was adopted for counts to accommodate overdispersion relative to Poisson distributions. Model fits were evaluated by inspecting conditional predictive ordinate distributions for uniformity (Czado et al. 2009) and calculating simple correlations between observed and predicted counts per site, year, and season. Models fit reasonably well with correlation coefficients averaging $0.78(\mathrm{SD}=0.12)$.

$\beta_{1}$ represented the average year effect across all survey units. It became apparent over the course of the analysis that there was considerable variation in temporal trends across survey units, and it was common to find trends for a species or group with positive, negative, and stable trends when examining survey units within which birds varied dramatically in relative abundance. To produce trend estimates weighted by species' or groups' relative abundances in survey units, we computed a composite year effect. To calculate a composite year effect, we sampled posteriors of model parameters $(n=10,000)$ and used the linear predictor to calculate a relative abundance per survey unit and year per sample. Then, for each sample, we summed the relative abundances per year across all survey units, and regressed that estimate against year. This produced the trend estimate reported for the aggregate of all survey units, a strategy common in trend analyses of data from other community science programs (Sauer and Link 2011; Soykan et al. 2016). In addition to this aggregate trend, we also computed local effects of year per survey unit using the linear predictor and posterior samples from global and random effects. Local abundance indices were computed as the sum of the global intercept and local intercept deviations. Local year effects were 
computed as the sum of the global year effect and local effect deviations.

We used two-way contingency tables to evaluate associations between fall and spring aggregate trend directions and species' foraging techniques, migration strategies, and taxonomic groups. With respect to trend direction, we classified aggregate trend data into two categories, positive or no trend. Only the Redhead (Aythya americana) had a negative aggregate trend observed in fall (see Results). Consequently, we did not include a negative direction category, and we dropped the single negative trend from our contingency table analyses. To increase numbers of species associated with foraging techniques, we lumped all species employing diving into a single category, aggregated species using surface dips and dabbles, and combined ground gleaners and probers. We dropped the sweeps and stalk and strike categories due to small numbers of species and the lack of a clear case for aggregation with other foraging techniques. Because $\geq 20 \%$ of categories for foraging technique and migration strategy contingency tables had expected values $<5$, we did not test the significance of associations using asymptotic $\chi^{2}$ distributions (Quinn and Keough 2002). Instead, we compared $\chi^{2}$ statistics to $\chi^{2}$ distributions generated via Monte Carlo resampling (10,000 resamples) of observed data as implemented in the R package coin (Hothorn et al. 2006; Hothorn et al. 2008).

Results Fall Of 37 species or groups, four displayed significant positive aggregate population trends during fall with posterior distribution median estimates ranging from 5.87 to $13.54 \%$ (Fig. 2, Table 4). One species, the Redhead, had a significant negative population trend of $-7.41 \%$ during fall. All remaining species or groups had stable aggregate fall trends. When looking at local trends for individual survey units, 17 species or groups possessed significant positive fall trends in up to five survey units, and these 17 included all four species or groups showing significant positive aggregate trends (Fig. 2, Table 4). The survey unit along the east side of Antelope Island had the greatest number of species or groups with positive local trends (Fig. 3). Negative local fall trends occurred in up to 10 survey units for 20 species or groups, and of these 20 , one possessed a positive ag- gregate trend (Table 4). Farmington and Ogden bays held several survey units with large numbers of negative local fall trends for species and species groups (Fig. 3). There were no associations between trend direction and foraging technique $\left(\chi_{2,26}^{2}=0.20, p=\right.$ $1.00)$, migration strategy $\left(\chi_{1,29}^{2}=2.72, p=0.23\right)$, or taxonomic group $\left(\chi_{2,29}^{2}=1.60, p=0.59\right)$.

Spring During spring, 14 species or groups showed positive aggregate population trends from 1.82 to $11.63 \%$ (Fig. 2, Table 4). All other species or groups had stable aggregate spring trends. Twenty-one species or groups had positive local trends in up to 11 survey units, and these 21 included all 14 species or groups showing positive aggregate trends (Fig. 2, Table 4). The unit with the largest number of positive local spring trends for species and groups was located in Farmington Bay (Fig. 3). Thirteen species or groups displayed negative local spring trends in as many as 5 survey units, and of these 13 , four possessed positive aggregate trends (Table 4 ). The greatest number of negative local spring trends for species and groups occupied the southernmost survey unit associated with Farmington Bay (Fig. 3). Foraging technique $\left(\chi_{2,27}^{2}=3.25, p=0.24\right)$, migration strategy $\left(\chi_{2,30}^{2}=2.33, p=0.15\right)$ and taxonomic group $\left(\chi_{2,30}^{2}=\right.$ $1.10, \mathrm{p}=0.72)$ were unassociated with aggregate trend direction.

Discussion Great Salt Lake and its associated wetlands are recognized for their importance to shorebirds, waterfowl, and other waterbirds (Aldrich and Paul 2002; Chipley et al. 2003; Wilsey et al. 2017), but relatively few studies have examined long-term trends for bird species at the lake (Sloan 1982; Paton 1997; King and Anderson 2005; Neill et al. 2017). Using a 21-year dataset (1997 - 2017), we examined trends in high-use and presumably, relatively high habitat quality areas of Great Salt Lake and its associated wetlands, and accordingly, we predicted a predominance of stable trends (Gill et al. 2001). We found that 36 of 37 bird species or species groups displayed stable or positive trends during fall and spring at Great Salt Lake. These stable and positive trends, in conjunction with potential declines of some species at other saline lakes experiencing declining water levels (Larson et al. 2016; Jones et al. 2019), further emphasize the importance of these survey units in or associ- 


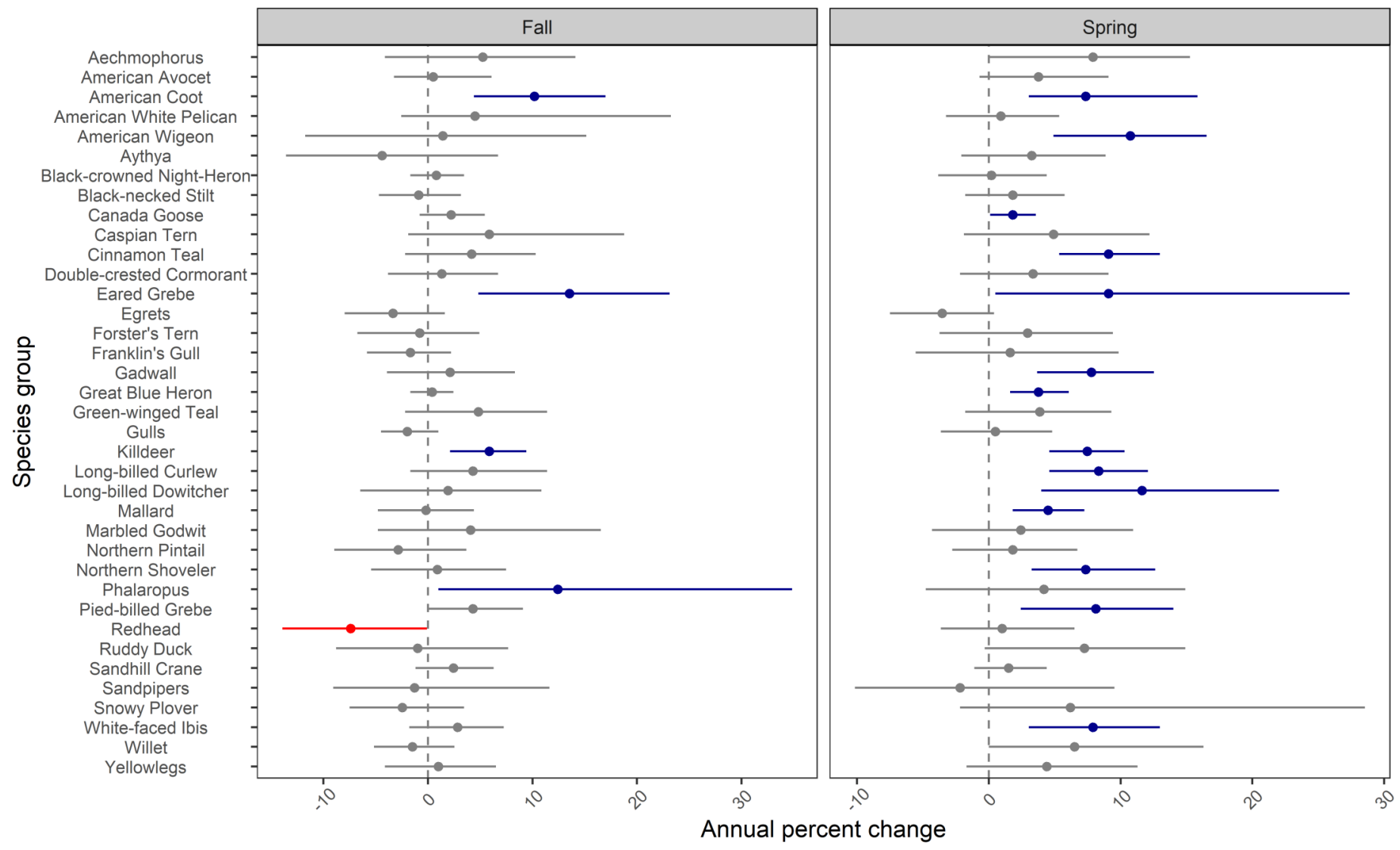

Fig. 2 Aggregate fall and spring annual trends for shorebird, waterfowl, and other waterbird species or groups across Great Salt Lake survey units between 1997 and 2017. The aggregate trend was based on summed relative abundances modeled for each survey unit annually and regressed against year. Point estimates represent the median of the posterior distributions for aggregate trends whereas horizontal bars represent the $95 \%$ credible interval. Significant positive and negative aggregate trends are in blue and red, respectively

ated with Great Salt Lake to migratory, waterdependent birds.

Intentional efforts to maintain stable and positive trends will require identifying factors regulating populations, designing and implementing conservation and management actions to prevent factors from limiting populations, and monitoring the success of actions. Given that the birds examined are migratory, ecological and demographic factors contributing to Great Salt Lake counts and trends might originate in other areas and seasons (Newton 2004). While many factors can affect trends at Great Salt Lake and other saline lakes, one receiving considerable regional and local attention is a reduction of water inflows affecting habitat amount, timing, and quality (e.g., by changing salinity) (Ivey and Herziger 2006; Wilsey et al. 2017; Senner et al. 2018; Haig et al. 2019). Securing adequate water supplies at key times of year is paramount to provide and sustain local and regional habitats for shorebirds, waterfowl, and other waterbirds (Ivey and Herziger 2006; Wilsey et al. 2017).

Stable and positive aggregate trends were not directly transferable to individual survey units as some species with stable or positive aggregate trends displayed negative trends in individual survey units. As an example, the Black-necked Stilt (Himantopus mexicanus), a shorebird species of regional focus (Thomas et al. 2013), declined significantly in nine survey units during fall despite showing a stable aggregate trend (Table 4). There were survey units in Farmington and Ogden bays that possessed relatively large numbers of declining trends for species or species groups, such as Franklin's Gull (Leucophaeus pipixcan) and Willet (Tringa semipalmata). Such observations based on trends for individual survey units can inform prioritizations of species and areas for 
bioRxiv preprint doi: https://doi.org/10.1101/2021.05.17.444474; this version posted May 17, 2021. The copyright holder for this preprint (which Submitted to $W$ atertifiby beer review) is the author/funder, who has granted bioRxiv a license to display the preprint in perpetuity. It is made

Table 4. Aggregate fall and spring annual trends for shorebird, water fowl, and other waterbird species or groups across Great Salt Lake survey units between 1997 and 2017. The aggregate trend was based on summed relative abundances modeled for each survey unit annually and regressed against year. Significant aggregate trends are bolded, and the $95 \%$ credible interval for each trend is reported parenthetically. For each species, the numbers of survey units with significant positive (+), negative (-), or stable (S) trends are also reported. The number of survey units modeled varied between 23 and 24 depending on the species or group.

\begin{tabular}{|c|c|c|c|c|}
\hline \multirow{2}{*}{$\begin{array}{l}\text { Species or } \\
\text { Group }\end{array}$} & \multicolumn{2}{|c|}{ Fall } & \multicolumn{2}{|c|}{ Spring } \\
\hline & $\begin{array}{l}\text { Aggregate } \\
\text { Trend }\end{array}$ & $\begin{array}{l}\text { Survey Unit } \\
(+/-/ \mathrm{S})\end{array}$ & $\begin{array}{l}\text { Aggregate } \\
\text { Trend }\end{array}$ & $\begin{array}{l}\text { Survey Unit } \\
(+/-/ \mathrm{S})\end{array}$ \\
\hline Aechmophorus & $\begin{array}{c}5.23 \\
(-4.11,14.11)\end{array}$ & $4 / 0 / 19$ & $\begin{array}{c}7.90 \\
(0.00,15.26)\end{array}$ & $3 / 2 / 18$ \\
\hline American Avocet & $\begin{array}{c}0.50 \\
(-3.25,6.08)\end{array}$ & $0 / 2 / 22$ & $\begin{array}{c}3.77 \\
(-0.70,9.09)\end{array}$ & $1 / 2 / 21$ \\
\hline American Coot & $\begin{array}{c}10.19 \\
(4.39,17.00)\end{array}$ & $3 / 10 / 10$ & $\begin{array}{c}7.36 \\
(3.05,15.84)\end{array}$ & $4 / 0 / 19$ \\
\hline American White Pelican & $\begin{array}{c}4.50 \\
(-2.57,23.24)\end{array}$ & $2 / 1 / 20$ & $\begin{array}{c}0.90 \\
(-3.25,5.34)\end{array}$ & $0 / 0 / 23$ \\
\hline American Wigeon & $\begin{array}{c}1.41 \\
(-11.75,15.14)\end{array}$ & $0 / 1 / 22$ & $\begin{array}{c}10.74 \\
(4.92,16.53)\end{array}$ & $7 / 1 / 15$ \\
\hline Aythya & $\begin{array}{c}-4.40 \\
(-13.58,6.72)\end{array}$ & $0 / 0 / 23$ & $\begin{array}{c}3.25 \\
(-2.08,8.87)\end{array}$ & $1 / 1 / 21$ \\
\hline Black-crowned Night-Heron & $\begin{array}{c}0.80 \\
(-1.69,3.46)\end{array}$ & $0 / 0 / 23$ & $\begin{array}{c}0.20 \\
(-3.83,4.39)\end{array}$ & $1 / 1 / 21$ \\
\hline Black-necked Stilt & $\begin{array}{c}-0.90 \\
(-4.69,3.15)\end{array}$ & $0 / 9 / 14$ & $\begin{array}{c}1.82 \\
(-1.78,5.76)\end{array}$ & $0 / 0 / 23$ \\
\hline Canada Goose & $\begin{array}{c}2.22 \\
(-0.80,5.44)\end{array}$ & $0 / 0 / 23$ & $\begin{array}{c}1.82 \\
(0.10,3.56)\end{array}$ & $4 / 4 / 15$ \\
\hline Caspian Tern & $\begin{array}{c}5.87 \\
(-1.88,18.77)\end{array}$ & $1 / 0 / 22$ & $\begin{array}{c}4.92 \\
(-1.88,12.19)\end{array}$ & $0 / 0 / 23$ \\
\hline Cinnamon Teal & $\begin{array}{c}4.19 \\
(-2.18,10.30)\end{array}$ & $1 / 1 / 21$ & $\begin{array}{c}9.09 \\
(5.34,12.98)\end{array}$ & $11 / 0 / 12$ \\
\hline Double-crested Cormorant & $\begin{array}{c}1.31 \\
(-3.83,6.72)\end{array}$ & $0 / 1 / 22$ & $\begin{array}{c}3.36 \\
(-2.18,9.09)\end{array}$ & $0 / 0 / 23$ \\
\hline Eared Grebe & $\begin{array}{c}13.54 \\
(4.81,23.12)\end{array}$ & $5 / 0 / 19$ & $\begin{array}{c}9.09 \\
(0.50,27.38)\end{array}$ & $1 / 4 / 19$ \\
\hline Egrets & $\begin{array}{c}-3.34 \\
(-7.97,1.61)\end{array}$ & $0 / 4 / 19$ & $\begin{array}{c}-3.54 \\
(-7.50,0.40)\end{array}$ & $0 / 2 / 21$ \\
\hline Forster's Tern & $\begin{array}{c}-0.80 \\
(-6.76,4.92)\end{array}$ & $0 / 1 / 22$ & $\begin{array}{c}2.94 \\
(-3.73,9.42)\end{array}$ & $0 / 4 / 19$ \\
\hline Franklin's Gull & $\begin{array}{c}-1.69 \\
(-5.82,2.22)\end{array}$ & $0 / 3 / 21$ & $\begin{array}{c}1.61 \\
(-5.54,9.86)\end{array}$ & $0 / 0 / 24$ \\
\hline Gadwall & $\begin{array}{c}2.12 \\
(-3.92,8.33)\end{array}$ & $1 / 3 / 19$ & $\begin{array}{c}7.79 \\
(3.67,12.52)\end{array}$ & $8 / 0 / 15$ \\
\hline Great Blue Heron & $\begin{array}{c}0.40 \\
(-1.69,2.43)\end{array}$ & $2 / 0 / 21$ & $\begin{array}{c}3.77 \\
(1.61,6.08)\end{array}$ & $2 / 0 / 21$ \\
\hline Green-winged Teal & $\begin{array}{c}4.81 \\
(-2.18,11.41)\end{array}$ & $2 / 0 / 21$ & $\begin{array}{c}3.87 \\
(-1.78,9.31)\end{array}$ & $4 / 0 / 19$ \\
\hline Gulls & $\begin{array}{c}-1.98 \\
(-4.50,1.01)\end{array}$ & $0 / 3 / 21$ & $\begin{array}{c}0.50 \\
(-3.63,4.81)\end{array}$ & $0 / 2 / 22$ \\
\hline Killdeer & $\begin{array}{c}5.87 \\
(2.12,9.42) \\
\end{array}$ & $3 / 0 / 21$ & $\begin{array}{c}7.47 \\
(4.60,10.30) \\
\end{array}$ & $6 / 0 / 18$ \\
\hline
\end{tabular}


Table 4 (continued). Aggregate fall and spring annual trends for shorebird, water fowl, and other waterbird species or groups across Great Salt Lake survey units between 1997 and 2017. The aggregate trend was based on summed relative abundances modeled for each survey unit annually and regressed against year. Significant aggregate trends are bolded, and the $95 \%$ credible interval for each trend is reported parenthetically. For each species, the numbers of survey units with significant positive $(+)$, negative (-), or stable (S) trends are also reported. The number of survey units modeled varied between 23 and 24 depending on the species or group.

\begin{tabular}{|c|c|c|c|c|}
\hline \multirow{2}{*}{$\begin{array}{l}\text { Species or } \\
\text { Group }\end{array}$} & \multicolumn{2}{|c|}{ Fall } & \multicolumn{2}{|c|}{ Spring } \\
\hline & $\begin{array}{l}\text { Aggregate } \\
\text { Trend }\end{array}$ & $\begin{array}{l}\text { Survey Unit } \\
\qquad(+/-/ \mathrm{S})\end{array}$ & $\begin{array}{l}\text { Aggregate } \\
\text { Trend }\end{array}$ & $\begin{array}{l}\text { Survey Unit } \\
\qquad(+/-/ \mathrm{S})\end{array}$ \\
\hline Long-billed Curlew & $\begin{array}{c}4.29 \\
(-1.69,11.41)\end{array}$ & $0 / 0 / 24$ & $\begin{array}{c}8.33 \\
(4.60,12.08)\end{array}$ & $7 / 0 / 17$ \\
\hline Long-billed Dowitcher & $\begin{array}{c}1.92 \\
(-6.48,10.85)\end{array}$ & $2 / 0 / 21$ & $\begin{array}{c}11.63 \\
(3.98,22.02)\end{array}$ & $4 / 0 / 19$ \\
\hline Mallard & $\begin{array}{c}-0.20 \\
(-4.78,4.39)\end{array}$ & $4 / 2 / 17$ & $\begin{array}{c}4.50 \\
(1.82,7.25)\end{array}$ & $4 / 0 / 19$ \\
\hline Marbled Godwit & $\begin{array}{c}4.08 \\
(-4.78,16.53)\end{array}$ & $0 / 0 / 24$ & $\begin{array}{c}2.43 \\
(-4.31,10.96)\end{array}$ & $0 / 0 / 24$ \\
\hline Northern Pintail & $\begin{array}{c}-2.86 \\
(-8.97,3.67)\end{array}$ & $0 / 2 / 21$ & $\begin{array}{c}1.82 \\
(-2.76,6.72)\end{array}$ & $0 / 0 / 23$ \\
\hline Northern Shoveler & $\begin{array}{c}0.90 \\
(-5.45,7.47)\end{array}$ & $1 / 1 / 21$ & $\begin{array}{c}7.36 \\
(3.25,12.64)\end{array}$ & $7 / 0 / 16$ \\
\hline Phalaropus & $\begin{array}{c}12.41 \\
(1.01,34.85)\end{array}$ & $1 / 0 / 23$ & $\begin{array}{c}4.19 \\
(-4.78,14.91)\end{array}$ & $0 / 0 / 24$ \\
\hline Pied-billed Grebe & $\begin{array}{c}4.29 \\
(-0.10,9.09)\end{array}$ & $2 / 0 / 21$ & $\begin{array}{c}8.11 \\
(2.43,14.00)\end{array}$ & $1 / 0 / 22$ \\
\hline Redhead & $\begin{array}{c}-7.41 \\
(-13.93,-0.10)\end{array}$ & $0 / 9 / 14$ & $\begin{array}{c}1.01 \\
(-3.63,6.50)\end{array}$ & $0 / 0 / 23$ \\
\hline Ruddy Duck & $\begin{array}{c}-1.00 \\
(-8.79,7.68)\end{array}$ & $0 / 1 / 22$ & $\begin{array}{c}7.25 \\
(-0.30,14.91)\end{array}$ & $3 / 0 / 20$ \\
\hline Sandhill Crane & $\begin{array}{c}2.43 \\
(-1.19,6.29)\end{array}$ & $1 / 1 / 21$ & $\begin{array}{c}1.51 \\
(-1.09,4.39)\end{array}$ & $0 / 0 / 23$ \\
\hline Sandpipers & $\begin{array}{c}-1.29 \\
(-9.06,11.63)\end{array}$ & $0 / 6 / 18$ & $\begin{array}{c}-2.18 \\
(-10.15,9.53)\end{array}$ & $0 / 1 / 23$ \\
\hline Snowy Plover & $\begin{array}{c}-2.47 \\
(-7.50,3.46)\end{array}$ & $0 / 0 / 24$ & $\begin{array}{c}6.18 \\
(-2.18,28.53)\end{array}$ & $0 / 0 / 24$ \\
\hline White-faced Ibis & $\begin{array}{c}2.84 \\
(-1.78,7.25)\end{array}$ & $1 / 0 / 22$ & $\begin{array}{c}7.90 \\
(3.05,12.98)\end{array}$ & $5 / 1 / 17$ \\
\hline Willet & $\begin{array}{c}-1.49 \\
(-5.16,2.53)\end{array}$ & $0 / 0 / 24$ & $\begin{array}{c}6.50 \\
(0.00,16.30)\end{array}$ & $1 / 5 / 18$ \\
\hline Yellowlegs & $\begin{array}{c}1.01 \\
(-4.11,6.50)\end{array}$ & $0 / 1 / 22$ & $\begin{array}{c}4.39 \\
(-1.69,11.29)\end{array}$ & $0 / 0 / 23$ \\
\hline
\end{tabular}

conservation and management. Further, the presence of stable, positive, and negative trends across individual survey units offers an opportunity to evaluate environmental drivers of changing species and group counts, and there are many candidates to consider, including the composition and dynamics of vegetation (Rohal et al. 2018), hydrology (Cavitt 2013), food resources (Conover and Caudell 2009), and others (Ma et al. 2010). Relationships between trends and envi- ronmental drivers could assist with the development of conservation or management strategies and tactics to maintain aggregate stable or positive trends.

When established, the present bird monitoring program was designed to permit trends to be examined, but evaluations of correlations with environmental drivers at the scale of individual survey units were not within scope (Paul and Manning 2002). Conse- 

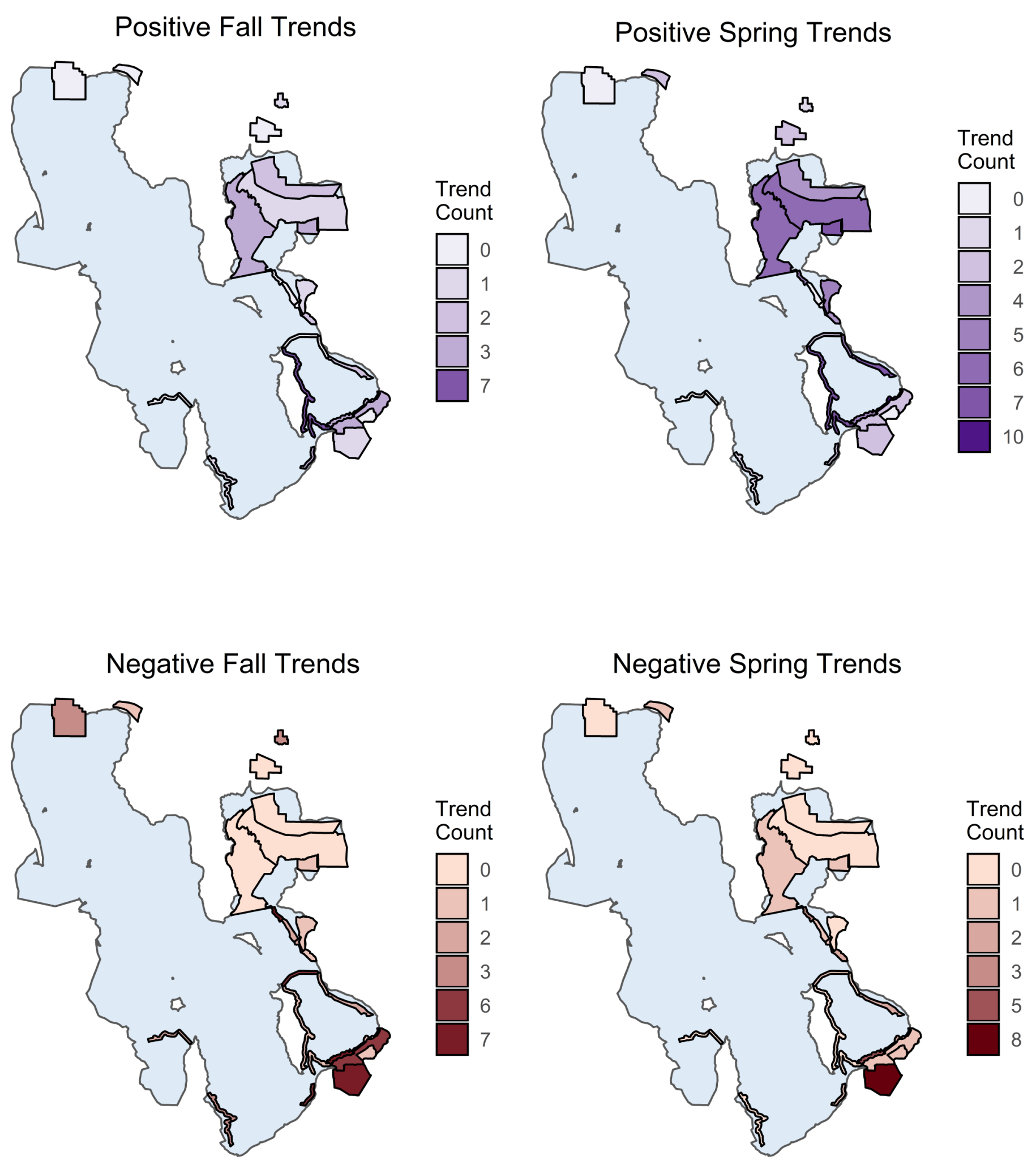

Fig. 3 Number of positive and negative seasonal trends (1997 - 2017) for species or groups at 24 individual survey units where the Great Salt Lake Ecosystem Program conducts long-term surveys for migratory shorebirds, waterfowl, and other waterbirds at Great Salt Lake, Utah. 
quently, data on potential drivers are not currently collected along with bird counts. There are long-term environmental monitoring efforts that temporally coincide with bird surveys, such as river inflow and lake elevation monitored by the U.S. Geological Survey (U.S. Geological Survey 2020), and previous studies have demonstrated the potential of relating these environmental data to bird counts for specific areas of Great Salt Lake (Cavitt 2013). Another potential source of environmental data is the use of remotely sensed imagery to map features of interest, such as habitat covers and changing vegetation composition (Long et al. 2017). Future efforts are needed to evaluate the feasibility of concurrently monitoring birds and environmental drivers, linking bird counts and temporally coincident environmental datasets, and possibly developing needed environmental datasets through remote sensing datasets and techniques. The authors are currently analyzing linkages among species and group counts and hydrological variables.

We did not find evidence that taxonomic group, migration strategy, or foraging technique affected the odds of a species displaying a positive versus stable trend. At times, our taxonomic groupings are used as the basis for local and regional management planning (Dybala et al. 2017; Tavernia et al. 2017; LMVJV Shorebird Working Group 2019), and foraging characteristics have been suggested or used to group birds to evaluate responses to management actions or environmental perturbations (Verner 1984; De Graaf et al. 1985; DeLuca et al. 2004). Given the greater distances they cover on an annual basis, longdistance migrants might be more sensitive than are short-distance migrants to environmental disturbances caused by climate change (cf. Galbraith et al. 2014). Species within taxonomic groups, migration strategies, or foraging groups can differ in specific habitat requirements, demography, geography, and the spatial and temporal scales at which they respond to their environments (Block et al. 1987; Noon et al. 2009), so species within these groups should not necessarily be assumed to show similar trends. Given the different species-specific trend directions within our groupings, we cannot recommend our taxonomic, migration strategy, or foraging technique groupings as meaningful for conservation or management planning at Great
Salt Lake and its associated wetlands. While our specific migration strategy classification did not relate to trend direction, we support calls for coordinated research, monitoring, and management across multiple sites and seasons to address the needs of migratory birds throughout their annual cycles (Runge et al. 2014; Marra et al. 2015).

For our trends analysis, we assumed that counts represent a constant proportion of the individuals within a survey unit across years. The proportion counted is a function of detection probability, or the probability of correctly identifying an individual present within the survey unit (Thompson 2002). If our assumption holds, our trends represent changes in numbers of individuals using survey units rather than being an artefact of a systematic change in detection probability. A variety of factors affect detection probabilities including species identity, observer identity and experience, survey method, habitat conditions (e.g., percentage of open water), season, time of day, weather conditions, ambient noise, and others (Johnson 2008). We do not attempt count comparisons between species, and thus, we are unconcerned about likely differences in detection probabilities across species. To the extent possible, we have attempted to control other factors through personnel decisions and standardized protocols.

The professional status of observers (i.e., wildlife biologists versus volunteers) has remained constant for the majority of survey units whereas individual observers may turnover from year-to-year. Personnel with long-term monitoring experience supervise counts of their respective survey units each year. Thus, we expected turnover in observers to increase the variability of counts, but we did not expect a consistent, directional change in detection probability because of changing observers. The implementation of an intensive training program for observers would reduce identification errors and variability among observers (Kepler and Scott 1981; Greenwood 2007). Training could help with identification of species that are currently lumped into groups. Survey methods and travel modes have changed for some units to different degrees with time, especially following 2001 surveys. However, including a random factor to control for pre -2001 and post-2001 survey status did not significant- 
ly change the proportions of positive or stable trends observed (unpublished data). Our survey protocols detail the seasonal and daily timing of surveys, and there has been no systematic change in survey timing from 1997 through 2017. An increased frequency of surveys during spring and fall seasons would reduce variability in counts across years. For individual species, our survey periods may be aligned to greater or lesser degrees with their primary periods of migration, and thus, where possible, we recommend comparing our trends to trends from species-specific survey efforts (e.g., for fall migration of the Eared Grebe, Neill et al. 2017). Acceptable weather conditions are specified with surveys not occurring if winds exceed a Beaufort scale of three $(18.5 \mathrm{~km} / \mathrm{hr})$ or precipitation is more than intermittent rain. While ambient noise levels are not recorded, the majority of species and individuals are observed visually, and for that reason, we do not expect potential increases in ambient noise to have biased outcomes from trend analyses. Thus, unless an unknown and uncontrolled factor is acting to affect detection probability, our trends reflect changes in the numbers of individuals using survey units.

We caution against an uncritical interpretation of the stable and increasing bird population trends at Great Salt Lake. Playas, an important shorebird habitat, are not currently represented among the established survey units and are threatened by human development (Sorensen et al. 2020). Further, within existing survey units, stable or increasing counts for a species within a fixed area (i.e., density) are not necessarily indicators that habitat quality is stable or improving (Van Horne 1983). As examples, birds may elect to settle in lower quality habitat as preferred habitat becomes saturated with conspecifics (Gill et al. 2001), or density may increase in remaining areas as habitat is lost from a landscape (Hagan et al. 1996). Metrics of habitat quality should assess both density and demographic measures of individual performance, i.e., per capita survival and reproduction, within an area (Van Horne 1983).

During migration, refueling rates and the amount of fuel deposited at stopover locations influence how long a bird must remain at a stopover and may affect subsequent survival and reproduction during the remainder of its annual cycle (Drent et al.
2003; Baker et al. 2004; Newton 2006). Accordingly, regional management planning for migrating waterfowl and shorebirds often uses bioenergetics models to quantify the amount of foraging habitat and food resources required to meet explicit population objectives (e.g., Petrie et al. 2013; Dybala et al. 2017; LMVJV Shorebird Working Group 2019). Petrie et al. (2013) applied a bioenergetics model to assess the adequacy of foraging habitat and food resources for nonbreeding waterfowl at Great Salt Lake. They found that food supply adequacy varied across waterfowl guilds, managed versus unmanaged lands, periods and seasons, and projected hydrologic conditions. Petrie et al. (2013) indicated that model improvements could be achieved with better estimates of wetland productivity and data on waterfowl resource selection. Despite interest in a bioenergetics model for shorebirds at Great Salt Lake (Thomas et al. 2013), no such efforts have been completed to date. To our knowledge, the bioenergetics needs of only a single waterbird species, the Eared Grebe (Conover and Caudell 2009), have been assessed in detail. We support applying and improving bioenergetics approaches at Great Salt Lake to identify clear habitat benchmarks to meet the foraging needs of migrating individuals and, consequently, to prevent foraging conditions at the lake from limiting bird populations.

Our trends analyses indicate that 36 of 37 examined species or species groups were stable or increasing during a 21-year period in the surveyed areas at Great Salt Lake, a site identified as important for shorebirds, waterfowl, and other waterbirds (North American Waterfowl Management Plan Committee 2004; Ivey and Herziger 2006; Petrie et al. 2013). Maintaining current trends will require setting explicit population (e.g., trend-based) objectives, identifying environmental factors potentially limiting populations, designing and implementing actions to address limiting factors, monitoring action outcomes, and adapting objectives, actions, and monitoring as needed based on observed outcomes (National Ecological Assessment Team 2006). Monitoring might be expanded to other low bird-use areas of the lake to facilitate detecting early species declines before they manifest themselves in highly used areas of presumably high habitat quality. Adding survey units in unrepresented habitat 
types (e.g., playas), additional duck clubs, and inland wetland areas would provide a more complete picture of wetland-dependent bird status and trends at Great Salt Lake. Careful consideration should be given to relationships among water inflows, lake elevation, and the ability of Great Salt Lake and its associated wetlands to meet the energetic needs of migratory shorebirds, waterfowl, and other waterbirds. Ultimately, the needs of migratory birds must be met throughout their annual cycles, so management and monitoring efforts at Great Salt Lake must be nested within larger regional and continental plans and programs to address shorebirds, waterbirds, waterfowl, and their habitats.

Acknowledgments We thank all the biologists, field technicians, and volunteers for collecting the field data used in these analyses. A. Manning, D. Paul, and C. Perschon provided key leadership in the early years of the monitoring program. P. Birdsey, G. Evans, F. Howe, K. Johnson, D. Mann, R. Norvell, and K. Poulsen helped with survey and database design and management. We thank A. Neville, C. Wilsey, E. Sorensen, K. Stockdale, M. Malmquist, M. Shoop, and S. Senner for comments that improved the manuscript.

\section{Literature Cited}

Aldrich, T.W. and D.S. Paul. 2002. Avian ecology of Great Salt Lake. Pages 343-374 in Great Salt Lake: an overview of change (J.W. Gwynn, Ed.). Utah Department of Natural Resources and Utah Geological Survey, special publication, Salt Lake City, Utah, USA.

Baker, A.J., P.M. González, T. Piersma, L.J. Niles, I. de Lima Serrano do Nascimento, P.W. Atkinson, N.A. Clark, C.D.T. Minton, M.K. Peck and G. Aarts. 2004. Rapid population decline in red knots: fitness consequences of decreased refueling rates and late arrival in Delaware Bay. Proceedings of the Royal Society B: Biological Sciences 271:875-882.

Barber, B. and J. Cavitt. 2012. Dietary review for aquatic birds utilizing Willard Spur, Great Salt Lake. Final Report to the Utah Division of Water Quality. 37 pp.

Baxter, B.K. and J.K. Butler. 2020. Climate change and Great Salt Lake. Pages 23-52 in Great Salt Lake biology: a terminal lake in a time of change (B.K. Baxter and J.K. Butler, Eds.). Springer, Netherlands.

Benoit, L.K. and R.A. Askins. 1999. Impact of the spread of Phragmites on the distribution of birds in Connecticut Tidal Marshes. Wetlands 19:194208.

BirdLife International and Handbook of the Birds of the World. 2018. Bird species distribution maps of the world. Version 2018.1. Available at http:// datazone.birdlife.org/species/requestdis

Block, W.M., L.A. Brennan and R.J. Gutiérrez. 1987. Evaluation of guild-indicator species use in resource management. Environmental Management 11:265-269.

Brown, S., C. Hickey, B. Harrington and R. Gill (Eds.) 2001. The U.S. Shorebird Conservation Plan, $2^{\text {nd }}$ ed. Manomet Center for Conservation Sciences, Manomet, MA.

Cavitt, J. 2006. Productivity and foraging ecology of two co-existing shorebird species breeding at Great Salt Lake, UT: 2005 - 2006 Report. Avian Ecology Laboratory Technical Report. AEL 0603. Weber State University, Ogden, UT. 38 pp.

Cavitt, J. 2013. Avian population analysis of the Willard Spur. Final Report to the Utah Division of Water Quality. 25 pp.

Chipley, R.M., G.H. Fenwick, M.J. Parr and D.N. Pashley. 2003. The American Bird Conservancy guide to the 500 most important bird areas in the United States. Random House, New York.

Clements, J.F., T.S. Schulenberg, M.J. Iliff, S.M. Billerman, T.A. Fredericks, B.L. Sullivan and C.L. Wood. 2019. The eBird/Clements Checklist of Birds of the World: v2019. Downloaded from http://www.birds.cornell.edu/ clementschecklist/download/

Conover, M.R. and J.N. Caudell. 2009. Energy budgets for Eared Grebes on the Great Salt Lake and implications for harvest of brine shrimp. Journal of Wildlife Management 73:1134-1139.

Cornell Lab of Ornithology. 2020. All About Birds. 
bioRxiv preprint doi: https://doi.org/10.1101/2021.05.17.444474; this version posted May 17, 2021. The copyright holder for this preprint (which Submitted not certified by peer review) is the author/funder, who has granted bioRxiv a license to display the preprint in perpetuity. It is made Submitted to Waterbirds and In Review available under aCC-BY-NC-ND 4.0 International license.

Cornell Lab of Ornithology, Ithaca, New

York. https://www.allaboutbirds.org, accessed on 18 Feb 2020.

Crewe, T.L. and S.T.A. Timmermans. 2005. Assessing biological integrity of Great Lakes coastal wetland using marsh bird and amphibian communities. Technical report, Environment Canada. Project \# WETLAND3-EPA-01.

Cruff, R.W. 1986. Great Salt Lake hypsographic data: unpublished U.S. Government memorandum, U.S. Geological Survey, Water Resources Division, Salt Lake City, Utah. 8 pp.

Czado, C., T. Gneiting and L. Held. 2009. Predictive model assessment for count data. Biometrics 65:1254-1261.

Dana, G.L. and P.H. Lenz. 1986. Effects of increasing salinity on an Artemia population from Mono Lake, California. Oecologia 68:428-436.

De Graaf, R.M., N.G. Tilghman and S.H. Anderson. 1985. Foraging guilds of North American birds. Environmental Management 9:493-536.

DeLuca, W.V., S.E. Studds, L.L Rockwood and P.P. Marra. 2004. Influence of land use on the integrity of marsh bird communities of Chesapeake Bay, USA. Wetlands 24:837-847.

Donnelly, J.P., S.L. King, N.L. Silverman, D.P. Collins, E.M. Carrera-Gonzalez, A. Lafón-Terrazas and J.N. Moore. 2020. Climate and human water use diminish wetland networks supporting continental waterbird migration. Global Change Biology doi:10.1111/GCB.15010

Downard, R., M. Frank, J. Perkins, K. Kettenring and M. Larese-Casanova. 2017. Wetland plants of Great Salt Lake: a guide to identification, communities, and bird habitat. Utah State University Extension, Logan, Utah.

Drent, R., C. Both, M. Green, J. Madsen and T. Piersma. 2003. Pay-offs and penalties of competing migratory schedules. Oikos 103:274-292.

Dybala, K.E., M.E. Reiter, C.M. Hickey, W.D. Shuford, K.M. Strum and G.S. Yarris. 2017. A bioenergetics approach to setting conservation objectives for non-breeding shorebirds in Califor- nia's Central Valley. San Francisco Estuary and Watershed Science 15(1):article 2.

Ehrlich, P.R., D.S. Dobkin and D. Wheye. 1988. The Birder's Handbook: a field Guide to the natural history of North American birds. Simon \& Schuster, New York.

ESRI. 2019. World Continents. [Layer Package]. Esri Data and Maps, https://www.arcgis.com/home/ item.html? $\underline{\mathrm{id}=a 3 \mathrm{cb} 207855 \mathrm{~b} 348 \mathrm{a} 297 \mathrm{ab} 85261743351 \mathrm{~d}}$

Ficklin, D.L., I.T. Stewart and E.P. Maurer. 2013. Effects of projected climate change on the hydrology in the Mono Lake Basin, California. Climate Change 116:111-131.

Galbraith, H., D.W. DesRochers, S. Brown and J.M. Reed. 2014. Predicting vulnerabilities of North American shorebirds to climate change. PLoS ONE 9:e108899. doi:10.1371/ journal.pone.0108899

Gill, J.A., K. Norris, P.M. Potts, T.G. Gunnarsson, P.W. Atkinson and W.J. Sutherland. 2001. The buffer effect and large-scale population regulation in migratory birds. Nature 412:436-438.

Greenwood, J.J.D. 2007. Citizens, science and bird conservation. Journal of Ornithology 148:S77124.

Hagan, J.M., W.M.V. Haegen and P.S. McKinley. 1996. The early development of forest fragmentation effects on birds. Conservation Biology 10:188 -202 .

Haig, S.M., S.P. Murphy, J.H. Matthews, I. Arismendi and M. Safeeq. 2019. Climate-altered wetlands challenge waterbird use and migratory connectivity in arid landscapes. Scientific Reports 9:4666.

Hothorn, T., K. Hornik, M.A. van de Wiel and A. Zeileis. 2006. A lego system for conditional inference. The American Statistician 60:257-263.

Hothorn, T., K. Hornik, M.A. van de Wiel and A. Zeileis. 2008. Implementing a class of permutation tests: the coin package. Journal of Statistical Software 28:1-23.

Ivey, G.L. and C.P. Herziger. 2006. Intermountain 
bioRxiv preprint doi: https://doi.org/10.1101/2021.05.17.444474; this version posted May 17, 2021. The copyright holder for this preprint (which Submitted not chertified by peer review) is the author/funder, who has granted bioRxiv a license to display the preprint in perpetuity. It is made Submitted to Waterbirds and In Review available under aCC-BY-NC-ND 4.0 International license.

West Waterbird Conservation Plan, Version 1.2. A plan associated with the Waterbird Conservation for the Americas Initiative. Published by U.S. Fish and Wildlife Service Pacific Region, Portland, Oregon.

Jacobs Engineering Group Inc. 2019. Great Salt Lake Integrated Model (GSLIM): an integrated water resource management tool for the Great Salt Lake Watershed. Phase II - GSLIM Evaluation. Document Version 1. Report to the Great Salt Lake Advisory Council.

Jeppesen, E., S. Brucet, L. Naselli-Flores, E. Papastergiadou, K. Stefanidis, T. Nõges, P. Nõges, J.L. Attayde, T. Zohary, J. Coppens, T. Bucak, R.F. Menezes, F.R.S. Freitas, M. Kernan, M. Søndergaard and M. Beklioğlu. 2015. Ecological impacts of global warming and water abstraction on lakes and reservoirs due to changes in water level and related changes in salinity. Trends in Aquatic Ecology 750:201-227.

Johnson, D.H. 2008. In defense of indices: the case of bird surveys. Journal of Wildlife Management 72:857-868.

Jones, A., D. Orr, and D. Cooper. 2019. The status of birds at the Salton Sea. National Audubon Society, New York, NY, USA.

Kepler, C.B. and J.M. Scott. 1981. Reducing bird count variability by training observers. Studies in Avian Biology 6:366-371.

King, D.T. and D.W. Anderson. 2005. Recent population status of the American White Pelican: a continental perspective. Waterbirds 28 (Special Publication 1):48-54.

Kluyver, H.N. and L. Tinbergen. 1953. Territory and the regulation of density in titmice. Archives Néerlandaises de Zoologie 10:265-289.

Kushlan, J.A., M.J. Steinkamp, K.C. Parsons, J. Capp, M.A. Cruz, M. Coulter, I. Davidson, L. Dickson, N. Edelson, R. Elliot, R.M. Erwin, S. Hatch, S. Kress, R. Milko, S. Miller, K. Mills, R. Paul, R. Phillips, J.E. Saliva, B. Sydeman, J. Trapp, J. Wheeler and K. Wohl. 2002. Waterbird Conservation for the Americas: The North American Waterbird Conservation Plan, Version 1. Waterbird
Conservation for the Americas, Washington, DC, USA. 78 pp.

Larson, R., J. Eilers, K. Kreuz, W.T. Pecher, S. DasSarma and S. Dougill. 2016. Recent desiccationrelated ecosystem changes at Lake Abert, Oregon: a terminal alkaline salt lake. Western North American Naturalist 76:389-404.

LMVJV Shorebird Working Group. 2019. Lower Mississippi Valley Joint Venture Shorebird Plan. Lower Mississippi Valley Joint Venture Office, Jackson, MS, USA.

Long, A.L., K.M. Kettenring, C.P. Hawkins and C.M.U. Neale. 2017. Distribution and drivers of a widespread, invasive wetland grass, Phragmites australis, in wetlands of the Great Salt Lake, Utah, USA. Wetlands 37:45-57.

Ma, Z., Y. Cai, B. Li and J. Chen. 2010. Managing wetland habits for waterbirds: an international perspective. Wetlands 30:15-27.

Marra, P.P., E.B. Cohen, S.R. Loss, J.E. Rutter and C.M. Tonra. 2015. A call for full annual cycle research in animal ecology. Biology Letters 11: 20150552. http://dx.doi.org/10.1098/ $\underline{\mathrm{rsbl} .2015 .0552}$

Meixner, T., A.H. Manning, D.A. Stonestrom, D.M. Allen, H. Ajami, K.W. Blasch, A.E. Brookfield, C.L. Castro, J.F. Clark, D.J. Gochis, A.L. Flint, K.L. Neff, R. Niraula, M. Rodell, B.R. Scanlon, K. Singha and M.A. Walvoord. 2016. Implications of projected climate change for groundwater recharge in the western United States. Journal of Hydrology 534:124-138.

National Ecological Assessment Team. 2006. Strategic habitat conservation: final report of the National Ecological Assessment Team. U.S. Geological Survey-U.S. Fish and Wildlife Service, Washington, D.C., USA.

Neill, J., M. Davison, J. Gonzales and J. Luft. 2017. 2016 Great Salt Lake Eared Grebe Aerial Photo Survey. Utah Division of Wildlife Resources, Salt Lake City. Unpublished report, 12 pp.

Newton, I. 2004. Population limitation in migrants. Ibis $146: 197-226$. 
Newton, I. 2006. Can conditions experienced during migration limit the population levels of birds? Journal of Ornithology 147:146-166.

Noon, B.R., K.S. McKelvey and B.G. Dickson. 2009. Multispecies conservation planning on U.S. federal lands. Pages 51-83 in Models for planning wildlife conservation in large landscapes (J.J. Millspaugh and F.R. Thompson III, Eds.). Elsevier, New York.

North American Waterfowl Management Plan Committee. 2004. North American Waterfowl Management Plan 2004. Implementation Framework: Strengthening the Biological Foundation. Canadian Wildlife Service, U.S. Fish and Wildlife Service, Secretaria de Medio Ambiente y Recursos Naturales, 106 pp.

Null, S.E. and W.A. Wurtsbaugh. 2020. Water development, consumptive water uses, and Great Salt Lake. Pages 1-21 in Great Salt Lake biology: a terminal lake in a time of change (B.K. Baxter and J.K. Butler, Eds.). Springer, Netherlands.

Okes, N.C., P.A.R. Hockey and G.S. Cumming. 2008. Habitat use and life history as predictors of bird responses to habitat change. Conservation Biology 22:151-162.

Paton, P.W.C. 1997. Distribution, abundance, and habitat use patterns of the Snowy Plover (Charadrius alexandrinus) at Great Salt Lake, Utah: American Birding Association and National Fish and Wildlife Foundation, final report.

Paul, D.S. and A.E. Manning. 2002. Great Salt Lake Waterbird Survey Five-Year Report (1997-2001). Publication Number 08-38. Great Salt Lake Ecosystem Program, Utah Division of Wildlife Resources, Salt Lake City.

Petrie, M., J. Vest and D. Smith. 2013. Waterfowl. Pages 4.2-4.58 in Intermountain West Joint Venture. 2013 Implementation Plan - Strengthening Science and Partnerships. Intermountain West Joint Venture, Missoula, MT.

Quinn, G.P. and M.J. Keough. 2002. Experimental design and data analysis for biologists. Cambridge University Press, Cambridge.
R Core Team. 2020. R: a language and environment for statistical computing $\mathrm{v}$ 4.0.2. R Foundation for Statistical Computing, Vienna, Austria. http:// www.R-project.org/, accessed 1 July 2020.

Roberts, A.J. 2013. Avian diets in a saline ecosystem: Great Salt Lake, Utah, USA. Human-Wildlife Interactions 7:158-168.

Rodewald, P. (Ed.). 2015. The Birds of North America: https://birdsna.org. Cornell Laboratory of Ornithology, Ithaca, NY.

Rohal, C.B., K.M. Kettenring, K. Sims, E.L.G. Hazelton and Z. Ma. 2018. Surveying managers to inform a regionally relevant invasive Phragmites australis control research program. Journal of Environmental Management 206:807-816.

Rue, H., A. Riebler, S.H. Sørbye, J.B. Illian, D.P. Simpson and F.K. Lindgren. 2017. Bayesian computing with INLA: a review. Annual Review of Statistics and Its Application 4:395-421.

Runge, C.A., T.G. Martin, H.P. Possingham, S.G. Willis and R.A. Fuller. 2014. Conserving mobile species. Frontiers in Ecology and the Environment $12: 395-402$.

Sauer, J.R. and W.A. Link. 2011. Analysis of the North American breeding bird survey using hierarchical models. Auk 128:87-98.

Senner, N.R., J.N. Moore, S.T. Seager, S. Dougill, K. Kreuz and S.E. Senner. 2018. A salt lake under stress: relationships among birds, water levels, and invertebrates at a Great Basin saline lake. Biological Conservation 220:320-329.

Simpson, D., H. Rue, A. Riebler, T.G. Martins, and S.H. Sørbye. 2017. Penalising model component complexity: a principled, practical approach to constructing priors. Statistical Science 32:1-28.

Sloan, N.F. 1982. Status of breeding colonies of White Pelicans in the United States through 1979. American Birds 36:250-254.

Sorensen, E.D., H.M. Hoven and B. Trusty. 2018. National Audubon Society's Gillmor Sanctuary Management and Conservation Plan. National Audubon Society, New York, New York. 
bioRxiv preprint doi: https://doi.org/10.1101/2021.05.17.444474; this version posted May 17, 2021. The copyright holder for this preprint (which Submitted not certified by peer review) is the author/funder, who has granted bioRxiv a license to display the preprint in perpetuity. It is made

Sorensen, E.D., H.M. Hoven and J. Neill. 2020. Great Salt Lake shorebirds, their habitats and food base. Pages 263-309 in Great Salt Lake biology: a terminal lake in a time of change (B.K. Baxter and J.K. Butler, Eds.). Springer, Netherlands.

Soykan, C.U., J. Sauer, J.G. Schuetz, G.S. LeBaron, K. Dale and G.M. Langham. 2016. Population trends for North American winter birds based on hierarchical models. Ecosphere 7(5), p.e01351.

Tavernia, B.G., J.D. Stanton and J.E. Lyons. 2017. Integrated wetland management for waterfowl and shorebirds at Mattamuskeet National Wildlife Refuge, North Carolina: U.S. Geological Survey Open-File Report 2017-1052, 43 pp. https:// doi.org/10.3133/ofr20171052

Thomas, S., B. Andres and J. Vest. 2013. Shorebirds. Pages 5.1-5.30 in Intermountain West Joint Venture. 2013 Implementation Plan - Strengthening Science and Partnerships. Intermountain West Joint Venture, Missoula, MT.

Thompson, W.L. 2002. Toward reliable bird surveys: accounting for individuals present but not detected. Auk 119:18-25.

Thompson, W.L., G.C. White and C. Gowan. 1998. Monitoring Vertebrate Populations. Academic Press Inc., San Diego.

U.S. Fish and Wildlife Service. 2019. National Wetlands Inventory website. U.S. Department of the Interior, Fish and Wildlife Service, Washington, D.C. http://www.fws.gov/wetlands/

U.S. Geological Survey. 2020. National Water Information System data available on the World Wide Web (USGS Water Data for the Nation), accessed 11 November 2020 at http://waterdata.usgs.gov/ nwis/

Van Horne, B. 1983. Density as a misleading indicator of habitat quality. Journal of Wildlife Management 47:893-901.

Verner, J. 1984. The guild concept applied to management of bird populations. Environmental Management 8:1-14.

Wilsey, C.B., L. Taylor, N. Michel and K. Stockdale. 2017. Water and birds in the arid west: habitats in decline. National Audubon Society, New York, New York.

Wurtsbaugh, W.A., C. Miller, S.E. Null, R.J. DeRose, P. Wilcock, M. Hahnenberger, F. Howe and J. Moore. 2017. Decline of the world's saline lakes. Nature Geoscience. https://doi.org/10.1038/ $\underline{\mathrm{NGEO} 3052}$

Zaifman, J., D. Shan, A. Ay and A.G. Jimenez. 2017. Shifts in bird migration timing in North American long-distance and short-distance migrants are associated with climate change. International Journal of Zoology https://doi.org/10.1155/2017/6025646 